\title{
Interfaith Dialogue, Diplomacy and the Cartoon Controversy
}

Samina Yasmeen

Islam has acquired a significant place in international politics since the terrorist attacks on the United States in September 2001. It is both demonised and engaged by those who acknowledge the role played by religion, particularly Islam, in partially determining the course of global and regional developments. For some, Muslims subscribe to an outdated form of allegiance to religious symbols and ideals of Islam with a propensity to engage in violence. Such analysts and practitioners of world politics emphasise the need to contain and curtail militancy linked to religious views by exploring and accepting the inherently violent and anti-democratic nature of Islam and Muslims. Others are reluctant to adopt a categorically negative view of Islam and opt for a more nuanced understanding of the diversity of views and practices among Muslims. Often acknowledging the role played by economic and political factors in creating militancy, they favour policies designed to engage "moderate” Muslims in the agenda of bridge building between Islam and the West. Interfaith dialogue has entered the lexicon of world politics: the analytical space traditionally reserved for secular understandings of global politics is gradually opening up to discourses centred round the salience of religion. At the same time, practitioners of world politics have focused on the need to build bridges across religious and civilisational divides. Governmental leaders and agencies are entering an arena where they have to deal with faith and its manifestations in today's world. Such a change raises a number of questions about the relationship between institutions and practices of traditional diplomacy and the demands of interfaith dialogue. Can the established 
institutions of diplomacy perform the role of bridge-builders across religious divides? Do our conceptions of diplomatic agents need to be revisited and broadened to include those who can adequately engage in such dialogues? What considerations and principles need to guide the course of such engagements to ensure their sustainability?

This chapter addresses these questions with reference to the developments surrounding the "cartoon controversy" of 2005-2006. It places the discussion of the controversy within the context of the emerging emphasis on interfaith dialogue. It argues that, despite the relatively greater emphasis in the post 9/11 era on the need for dialogue, the controversy initially exhibited two divergent views on the notion of sacred. Diplomatic institutions, symbols and practices emerged both as communicators of these differences as well as the targets of the resulting anger among the Muslim world. At the same time, the controversy manifested the relevance of alternative agents who played a role in creating and/or containing the divergent discourses on sacred spaces. The list of these agents included, among others, business interests who wanted to contain the fallout from the controversy for economic reasons. The experience suggests that increasingly efforts need to be coordinated among traditional and alternative agents of diplomacy in the religio-civilisational arena. Such efforts, the chapter argues, need to be guided by rules of engagement which reflect respect, equality and fairness to all parties involved if the project of building bridges across faiths is to be successful.

\section{DIPLOMACY AND INTERFAITH DIALOGUE: AN EMERGING TREND}

Diplomacy can be defined as the process and art of communication and negotiations with the ultimate purpose of containing, managing and/or resolving disputes. The process 
continues during conflicts as well, with parties involved seeking ways to either end the confrontation or to reduce the ultimate costs incurred by those involved in the dispute. The history of such interactions and processes is not new: tribal structures as well as Greek city-states engaged in what can be safely identified as diplomatic engagements. The modern understandings of diplomacy, however, date back to the Italian traditions of diplomatists who communicated the views and opinions of their respective sovereigns to others. Building on these traditions, diplomatic institutions and traditions have emerged in parallel to the rise of state as the main unit of global politics. Diplomacy has been accepted and acknowledged as the domain in which a state operates and communicates its views to other states. The process occurs against the backdrop of the balance of power: the relative equilibrium or the absence of it determines the tenor of diplomatic exchanges as well as the issue areas covered by states.

Interfaith dialogue, in contrast, operates in the realm of beliefs and ideas of sacredness. The aim of the dialogue is essentially not to eliminate or reduce conflict between followers of different religious traditions but rather to promote an acceptance of difference. This is essentially due to the fact that religion invokes and evokes a belief and a fundamental commitment to notions of truth and sacred. Followers of different religious traditions view human place and its relationship to the sacred differently. Instead of establishing the primacy of one fundamental commitment over another, therefore, interfaith dialogue focuses on finding spaces where mutual coexistence is possible.

Traditionally the established religious institutions of different faiths had dominated the process. Religious clergy engaged in intellectual debates to establish the validity of religious views held by each other. Sovereigns representing different religious 
traditions often supported them in these processes. Sometimes these sovereigns also coopted followers of other religions into their state structures as advisors and ministers. This enlarged the space in which ideas and practices of coexistence were developed. The Abbasids, for instance, employed and promoted Jewish and Christian scientists and artists. Similarly, Emperor Akbar actively engaged Hindu advisors as a mechanism of building interfaith links with the ultimate aim of strengthening the Mughal Empire. Gradually, however, the interfaith dialogue shifted primarily to the non-state sphere. Societal groups (including those from religious denominations) engaged in discussions and activities to build understanding across faith boundaries. During the post Second World War era, therefore, the agency of interfaith dialogue rested with non-state actors who primarily engaged groups in their local areas. In the Nuba mountains of Sudan, for example, Christians and Muslims lived together peacefully with their respective leaders showing tolerance and active cooperation with each other. A Christian built both the mosque and church in the region (Flint, 1995). Similarly, in Indonesia the syncretic traditions continued to provide the basis on which Muslim, Christian and Hindu communities coexisted in the largest Muslim state.

The relegation of interfaith dialogue to the societal sphere reflected the nature of the Cold War system with its emphasis on rationality coupled with balance of power calculations. Religion and culture was considered to reside outside the domain in which states conducted their relationships. The trend did not change despite the emergence of transnationalism in the 1970s and the increased migration of Muslims into a number of western states. The Gulf Crisis and War of 1990-1991 followed by the end of the Cold War heralded an end to such attitudes: as Saddam Hussein used the Islamic card to 
muster support for his ill-conceived invasion of Kuwait, Islam attracted attention as a new factor in international politics. Partly such attention stemmed from the views held by some Muslims that the west had substituted the "red menace" with the "green menace" as the main target of its attention. The discourse of civilisational clash in 1993 reinforced such views. As analysts debated the validity of Huntington's ideas of an inherent clash between Islam and the west, some came to accord this thesis the status of an established reality. Against the background of such views, some societal groups (particularly in western liberal democracies) opted to "learn” more about Islam. This search for knowledge and understanding invigorated the process of interfaith dialogue. Mostly guided by Christian churches of all denominations, it took the form of localised meetings among Muslims and members of other religious denominations. At the same time, interfaith organisations were either created or strengthened in countries with a relatively longer history of Muslim immigration.

The increased frequency of interfaith initiatives in the societal sector also contributed to some governmental leaders to begin to focus on the need to build bridges across civilisational lines. Prince Hasan bin Talal of Jordan took the lead in this process. Apart from emphasising the need to build understanding across religious divides, he established an Institute which encourages the exchange of information between different groups (ArabicNews.com, 1998). Prince Charles in Britain adopted a similar approach by supporting the Oxford Centre for Islamic Studies. President Khatami of Iran also floated the idea of a Dialogue of Civilisations with an emphasis on cross-cultural understandings.

The process gained momentum after the 9/11 terrorist attacks on the United States. The US-led war on terror and the increased focus on Muslim militancy created 
fear and a discourse of the west targeting Islam. The necessity to counter such discourse as a necessary corollary to engaging Muslim states and societies in countering terrorism contributed to a new found preference for interfaith dialogue among state actors. Keen to highlight the appreciation that the United States was aware of the diversity among Muslims and was only targeting militants, Washington took the lead in engaging Muslim leadership. In addition to meeting leaders from the American Muslim community, the Bush administration also set the tradition of diplomats promoting themselves as agents of interfaith understanding. Ambassadors posted to Muslim countries like Pakistan, for example, joined other Muslims in fasting during the month of Ramadan. They also began sending greetings to Muslims during the festivals celebrating the end of Ramadan (Eidul-Fitr) and Hajj (Eid al-Adha). Even in some western liberal democracies, American diplomats engaged local Muslim populations and extended felicitations during the Islamic festive seasons.

This new blurring of the boundaries between the traditional roles of diplomats and interfaith organizations occurred in other countries as well. The process was aided by two parallel trends: western liberal democracies (including Australia) also wanted to reinforce their understanding of the nuanced differences among Muslims. At the same time, governments in Muslim majority states sought to legitimise their participation in the war on terror and counter allegations that they had become partners in a western agenda of subjugating Muslims. Keen to alter the domestic balance between radicalised and moderate population, they opted for a role as bridge builders across religious divides. This complementarity of interests resulted in some low-key interaction among members of Muslim majority states with those from western liberal societies. In some cases, 
countries like Australia engaged some Muslim representatives to participate in interfaith dialogue at the regional level. The process invariably involved diplomatic institutions that had previously not specifically acknowledged the role of religion.

The relative quiet diplomacy was combined with more overt and symbolically significant references to the need for interfaith understanding. After the terrorist attacks on the United States, Pakistan’s President Musharraf promoted the idea of enlightened moderation with an emphasis on building links with the West. Such unilateral declarations were soon complemented by joint calls for cooperation among followers of different religions. In September 2004, the newly elected Spanish Prime Minister Jose Luis Zapatero mooted the idea (later co-sponsored by Turkey) of creating an UNsponsored "alliance of civilisation between the Western world and the Arab and Muslim world” (Fraerman, 2004; BBC, 2004). The alliance was to serve as a mechanism for “deepening political, economic, cultural and educational ties” between the two civilisations. Then UN Secretary General, Kofi Annan, formally endorsed the project in September 2005 with the setting up of a high-level group for the "Alliance of Civilisations”. The composition of the group, which held its first meeting in November 2005, manifested the realisation among decision-makers that state and civil society structures needed to cooperate in the agenda of interfaith dialogue. The nominated members of the Alliance were drawn from government institutions, international organisations, academia and eminent leaders from across the globe. In addition to former Iranian President Khatami, Bishop Desmond Tutu and former Indonesian Foreign Minister Ali Alatas, it also included renowned analysts like Karen Anderson and John Esposito who have made their mark in broadening understandings of Islam and other 
religious traditions (United Nations, 2005). The High-Level group was charged with the task of assessing the nature of, and response to, the threat to peace and security from religious extremism at both the institutional and societal level. Importantly, it identified governments, international organisations and societies as the stakeholders in the process of combating religious extremism and building understanding. Those engaged in the art of diplomacy in the new millennium were clearly indicating their acceptance and support for multidimensional interaction and cooperation in an era of increased emphasis on religious identities.

\section{THE CARTOON CONTROVERSTY: DIFFERING INTERPRETATIONS}

The controversy surrounding the publication of cartoons of Prophet Mohammad occurred against the backdrop of these efforts to build bridges across religious divides. Commonly dubbed as the "cartoon controversy", it started with the printing of 12 caricatures of the Prophet in a Danish newspaper, Jyllands-Posten, on 30 September 2005. Drawn by a number of cartoonists, these ranged from the Prophet depicted as a wanderer accompanied by a donkey to one of him with a halo which resembled horns. The most controversial cartoons showed Prophet Mohammad wearing a turban carrying the shahadah $^{i}$ in front and with a lit fuse, and one of him holding a dagger while flanked by two niqab-clad women. ${ }^{\mathrm{ii}}$ In the first phase of the controversy, which could be identified as the silent protest, Danish Muslims complained about the publication of the cartoons and demanded an apology from Jyllands-Posten. They also tried to engage the Danish government in securing the apology and controlling what they perceived to be growing Islamophobia in Denmark. The failure to secure the apology or governmental support led 
a group of Danish Muslims to tour the Middle East with information about the cartoons and other perceived indications of anti-Muslim trends in Denmark. In early January 2006, the second and violent phase of the controversy started: when a Norwegian newspaper Magazinet reprinted the cartoons, Muslim frustration and anger grew. That newspapers from other states, including Bulgaria, France, Germany, Italy, Spain, Switzerland, New Zealand and Ukraine reprinted these cartoons further aggravated the situation. An actionreaction phenomenon ensued. Instead of remaining confined to a debate within Denmark, it emerged as an issue involving heated debates on the place of Islam in today's world and the inherent incompatibility between western and Muslim civilisations. The negative reactions also took the form of violent demonstrations across a number of Muslim majority states costing loss of lives and property. It invariably involved governments of the Muslim and non-Muslim world.

Both the phases of the controversy were marked by two diametrically opposed views on the logic and appropriateness of publishing these cartoons. Although there were some slight variations, these views could broadly be categorised as representing those held by western societies on the one hand and the Muslim communities on the other. The predominant view among the western societies assigned priority to the right to freedom of speech and expression. In fact, such views had formed the basis for the process which led to the original publication of the cartoons. In 2004, a Dutch film-maker Theo Van Gogh was unfortunately murdered after producing the movie, Submission. The movie depicted the plight of Muslim women who are abused and tortured by men using Islamic injunctions. While the message resembled the criticism voiced by a number of Muslim feminists, the medium adopted reflected a lack of understanding of the place accorded to 
religious scriptures. That Qur'anic verses were inscribed on the nearly naked body of a woman recounting the abuses perpetrated in the name of Islam infuriated some Muslims. Although the movie did not attract the same attention among Muslims as the cartoons, the violent response to its production had regional repercussions. Subsequently, a Danish writer, Kare Bluitgen, could not find artists willing to draw illustrations for his book for children on Prophet Mohammad. The atmosphere of fear caused the cultural editor of Jyllands-Posten, Flemming Rose, to invite 40 cartoonists to draw caricatures of the Prophet. ${ }^{\text {iii }}$

Once the cartoons were published, the dominant argument remained one of supporting freedom of speech in western secular societies without fear of retribution. In Denmark specifically, it was argued, democratisation and the introduction of the parliamentary system had allowed Danes the freedom to publish their ideas "in print, in writing, and in speech” subject to them being held responsible in a court of law. But more broadly, it was argued that the European Convention on Human Rights and the International Covenant on Civil and Political Rights also endorsed these rights (cited in Wikipedia, 2006). Coupled with the focus on secularism, it was claimed, "the West” had moved to a stage where making fun of religious views and sensitivities was considered acceptable. Newspapers in western societies referred to this view as justification of their decision to reprint the cartoons as the controversy entered the second phase.

Such views on the admissibility of publishing cartoons of Prophet Mohammed stood in marked contrast to the dominant opinion among Muslims. ${ }^{\text {iv }}$ For them, the cartoons had violated the sacred space allocated to Prophet Mohammad in Islam as the messenger of God's message. Drawing upon the interpretation that prohibits pictorial 
depiction of all human beings, Muslims have developed a relative consensus in favour of not drawing illustrations of Prophet Mohammad. Some exceptions to this consensus do exist, but even those accepting the practice of pictorially representing the Prophet clearly articulate that it must be done with the respect and veneration due to him by virtue of his religious status. While the debate on his infallibility as a human being is an ever-present feature of Muslim society, he is respected and revered as God's chosen messenger who communicated the message of Islam to humanity (and not just Muslims). Specifically for Muslims, he is seen as the teacher, the guide and the spiritual leader who gave life to the Qur'anic injunctions by demonstrating and interpreting their relevance in daily life. To put it simply, along with the Qur'anic injunctions (which are believed by Muslims to be God's message), Prophet Mohammad is believed to occupy the sacred space that must not be violated. The cartoons published by Jyllands-Posten were seen by Muslims as blatantly ignoring such limits in the name of freedom of speech. Given that they were published as the perceived Islamophobia increased in Europe, the cartoons also acquired a symbolic value in political terms: they were seen as evidence of a concerted effort/conspiracy to marginalise and violate the rights of Muslims and Islam globally.

\section{THE RELEVANCE OF TRADITIONAL DIPLOMACY?}

Against the background of these different views on the meaning and appropriateness of the cartoons, and the violence related to the controversy, the question arises as to what lessons can be drawn about the interface between traditional diplomacy and interfaith dialogue? 
From the outset, the controversy demonstrated the continued but limited relevance of traditional diplomatic channels of communication in dealing with interfaith issues. The first signs of such limits emerged during the "silent protest phase" of the controversy. Within a fortnight of the cartoons' publication in Denmark, ambassadors and diplomatic representatives from Turkey, Saudi Arabia, Iran, Pakistan, Egypt, Indonesia, Algeria, Bosnia and Herzegovina, Libya, Morocco and Palestine wrote a letter on 12 October 2005 to Denmark’s Prime Minister, Anders Fogh Rasmussen. They complained about the “on-going smearing campaign in Danish public circles and media against Islam and Muslims", and included the publication of the "demeaning caricatures of Holy Prophet Mohammad (PBUH)” as one of the examples. They argued that "Danish press and public representatives should not be allowed to abuse Islam in the name of democracy, freedom of expression and human rights, the values that we all share”. The letter hinted that if continued, the smear campaign could "cause reactions in Muslim countries and among Muslim communities in Europe". The letter also asked the Prime Minister to "take all those responsible to task under law of the land in the interest of inter-faith harmony" and requested an urgent meeting with him (Letter by the Muslim Representatives, 2005).

It appears that the Danish prime minister did not fully appreciate the sentiments that had prompted the ambassadors to use diplomatic channels to express their anguish and concern. Instead, approaching the issues from different standpoint, not only did he refuse to meet the ambassadors but also declined to get involved in the issue of cartoons' publication. This response rested on the premise that the Danish government did not control the news media and could not contravene the state's laws on the freedom of speech. But he did mention the right of those offended to bring expressions and acts of 
blasphemous or discriminatory nature to the courts. Despite such a response, the Egyptian ambassador continued to communicate his government's displeasure over the publication of the cartoons through diplomatic channels. He even sent letters to the UN SecretaryGeneral expressing regret at the publication of cartoons and requesting categorical "statements from the Danish Government on the need to respect all religions and desisting from offending their devotees” (cited in Wikipedia, 2006). As a group of Danish Muslims toured the Middle East with a dossier including the "offending cartoons”, governmental representatives of Muslim states further got involved in the episode. The dossier was presented to the meeting of the Organisation of Islamic Conference (OIC) in December 2005.

The second phase of the cartoon controversy reaffirmed the continued but limited relevance of traditional diplomatic institutions. As the information about the cartoons was publicised in the Muslim world, demonstrations were held in a number of Muslim countries to express their anger. The demonstrators targeted Danish, Norwegian, German and British embassies in Indonesia, Pakistan, Syria, Iran, Lebanon and other Middle Eastern states to vent their anger at the perceived insults to Prophet Mohammad. So strong was the reaction that Denmark government was propelled to withdraw its diplomatic staff from some countries at a short notice. Meanwhile Saudi Arabia had already recalled its ambassador to Denmark, while other Muslim states issued strong statements directly and through their respective embassies expressing their anger at the publication of the cartoons. At one level, these developments suggested the inability of traditional diplomatic institutions to deal with religious issues. However, that some Muslim states chose the symbolism of recalling ambassadors, and others targeted the 
embassies of "offending countries" paradoxically also reflected the continued relevance of these institutions. Furthermore, it is interesting to observe how the interface of governance and diplomacy appeared quite clearly in this case with diplomats launching appeals both through and to international institutions of governance, such as the OIC and the UN, when their attempts at bilateral diplomacy did not prove as successful as hoped.

The second phase was also marked by active use of diplomacy to contain the damage done by the publication of the cartoons. The Danish foreign minister issued statements that initially expressed an acceptance that the cartoons had hurt Muslims. In a letter to the Secretary General of the Arab League and the Secretary General of the OIC on 6 January 2006, for instance, the Danish foreign minister, Dr per Stig Moller stated that "the Danish Government understood that Muslim circles had felt hurt and offended by the Danish newspaper's drawings”. He also stressed that his government "respects Islam as one of the world's major religions and that it has no wish and no agenda to insult, mock or in any other way behave disrespectfully towards Muslims” (Ministry of Foreign Affairs of Denmark, 2006a). As the violent demonstrations increased, the Danish prime minister and foreign minister also distanced themselves from the decision to publish the cartoons. On 31 January 2006, for instance, the Danish prime minister categorically stated that he would not have "chosen to depict religious symbols" in the way adopted by Jyllands-Posten (Ministry of Foreign Affairs of Denmark, 2006c). Three days later, both the prime minister and the foreign minister called a meeting of ambassadors to highlight their commitment to respecting Islam as a religion, and refuting some of the rumours that were circulating about the mistreatment of Islam and Muslims 
in Denmark. The emphasis was on the country’s unqualified respect for Islam and its commitment to cooperation with Muslim states (Ibid). ${ }^{\mathrm{v}}$

The Danish government made active use of cyberspace to communicate these conciliatory messages. The statements by Danish leaders were given prominence on the website of the Ministry of Foreign Affairs of Denmark. Specifically, they were publicised through the diplomatic posts in a number of Muslim states. The websites included a series of statements aimed at dispelling the misconception that the publication of the cartoons was reflective of Danish lack of respect for and discrimination against Muslims and Islam. One Question and Answer section, for example, stressed that there had been no cases of the Koran being burnt in Denmark, that Muslims are not persecuted in Denmark and do have the right to demonstrate. Refuting some other rumours that emerged among sections of Muslims across the world in the wake of the controversy, the same section clarified that the Danish government did not intend rewriting the Koran or making a film about the Prophet Mohammad. It also highlighted that the Danish prime minister, and the foreign minister had expressed regret at the publication of the cartoons and that it was possible to prosecute Jyllands-Posten for publishing the cartoons. Equally important, the website identified the Danish government's commitment to invigorating interfaith dialogue as a means of preventing such events in future. These and other similar statements remained easily accessible months after the cartoon controversy died down. The websites of Danish embassies in Saudi Arabia and Pakistan, for instance, carried links to statements by the Prime Minister and Foreign Minister as late as December 2006. 
Given that the cartoon controversy had spilled across the borders into other European states and engulfed a number of Muslim countries, traditional diplomatic institutions also became active in other states and in institutions of international governance. A number of Muslim leaders made strong statements condemning the publication of the cartoons. Their diplomatic representatives communicated such messages to the host states in the West. ${ }^{\mathrm{vi}}$ The response from western states reflected a growing understanding of the role played by religious sensitivities: while referring to the freedom of speech, these representatives increasingly acknowledged the hurt caused by the publication of the caricatures. Significantly, they placed the controversy within the broader context of inter-civilisational relations. A growing emphasis was placed on the need to build understanding between Muslims and western societies. The European Union's High Representative for the Common Foreign and Security Policy, Javier Solana, visited Muslim states including Egypt and talked of his "profound desire to recuperate relations between the European Union and the Muslim world” (Turkish Press, 2006). Other European leaders also articulated such views. Spain, which had played a pivotal role in the creation of the UN Alliance of civilisation urged the Vatican to support an initiative promoting understanding between Arabs and the west. The European Union also signed a joint statement with the Organization of Islamic Conference and the United Nations in February 2006 on protecting religious symbols. ${ }^{\text {vii }}$

Despite the flurry of these diplomatic activities and statements by governmental leaders, the violent phase of the cartoon controversy did not end quickly. This, in turn, highlighted the increasing role of non-state actors in undermining or sidestepping the traditional diplomatic channels of communication on interfaith issues. To begin with, 
non-state actors had created the crisis: Jyllands-Posten had published the cartoons and had refused to apologise for the offence caused to Danish Muslims. The group of Danish imams, in turn, prepared a dossier detailing instances of persecution of and discrimination against Islam and Muslims in Denmark. Not all the information contained in the dossier was factually correct. But by publicising it to the wider Muslim community, they sought to strengthen their position vis-à-vis other local Danish groups in a religious-based dispute. Given the special status accorded to Prophet Mohammad among Muslims, such support was almost guaranteed. This is not to suggest that differences did not exist among Muslims on the appropriate response to the offence caused by the publication. While some suggested a measured and effective response, other favoured the strongest possible expression of anger at the disrespect showed to a religious icon in Islam. Irrespective of the lack of clarity on what such responses entailed, a relative consensus existed among Muslims around the world at the need to address the hurt caused by the publication of cartoon. Instead of being restricted to debates on the pros and cons of freedom of speech in Denmark, the controversy shifted into a new space where the cartoons emerged as the symbol of western hostility towards Islam and Muslims. The response took the form of violent protests in some cases. Effectively, therefore, the cartoon controversy clearly demonstrated the ability of non-state actors to become initiators of inter-faith dialogue embroiling governmental representatives as well.

Paradoxically, the controversy also established the limits to the ability of nonstate actors to control the direction of events related to inter-faith issues. Having circulated the cartoons and the coverage of discriminatory acts and speeches by Danish civil society groups, the imams lost control of the response in the second phase. As the 
demonstrations turned violent and western newspapers continued to either reprint the cartoons or express an intention to do so, the group of Danish imams who had publicised the caricatures softened their demands. The call for an apology was replaced with demands that respect for Prophet Mohammad be restored and that he be described "as the man he really was in history, and that he gets the respect he deserves” (Gudmundsson, 2006). But the ferocity of the demonstrations prompted Jyllands-Posten to soften its stand as well. After initially refusing to apologise for publishing the cartoons, the editorin-chief, Carsten Juste (2006), issued an apology on 30 January 2006 arguing that "the drawings were not intended to be offensive, nor were they at variance with Danish law”. But he admitted that the cartoons had "indisputably offended many Muslims” and apologised for it without any qualification. He went on record that the cartoons did not constitute part of a campaign against Muslims in Denmark and the rest of the world: "Because of the very fact that we are strong proponents of the freedom of religion and because we respect the right of any human being to practice his or her religion, offending anybody on the grounds of their religious beliefs in unthinkable to us. That this happened was, consequently, unintentional.” (Juste, 2006)

The apology was accepted by Muslims in Denmark indicating that they were prepared to move into a new stage of reconciliation and building bridges between Muslims and the wider Danish society. But, despite these exchanges and announcements, the demonstrations did not subside. If anything, they continued unabated with the death toll mounting. It was obvious that an interfaith issue, once raised by societal groups, could become hostage to emotions. Political groups, as was the case in Pakistan, could 
also exploit these emotions as part of their own machinations (Khan, 2006). Ultimately it was only when the anger subsided that the situation came under control.

\section{BUSINESS INTERESTS AND INTERFAITH DIALOGUE}

The cartoon controversy also brought into focus the role of business interests as alternative agents of diplomacy. The phenomenon is not new: the transnationalism that emerged at the turn of the 1970s had already established the relevance of "new diplomats" in world politics. The pro-Arab attitude adopted by Aramco in the 1973 ArabIsraeli war was a vivid example of this role. Instead of following the trend set by the United States, the oil company sided with the Arab hosts and participated in the oilembargo. Clearly, its economic interests had dictated its stance in a regional conflict with long-term implications for developments in the area. But the events surrounding the publication of Prophet's caricatures suggested that the environment in which these new diplomats have to perform is more complex than before. At the same time, it also emerged that business interests do have the space for and ability to play a role, albeit limited in nature, in issues of religious nature. In this particular situation, the case of Danish and Norwegian exports to the Middle East amplified this role.

As the opinions diverged along essentially religious/civilisational lines with western states reaffirming the right to freedom of speech against the Muslim demands for an apology, an action-reaction phenomenon was set in motion at the societal level as well. Angered by the predominant view among Danish people that Jyllands-Posten need not apologise for the caricatures and the Norwegian paper Magazinet's decision to reprint them, civil society groups in the Middle East pressed for a boycott of Danish and 
Norwegian imports. SMS messages were sent around the region urging all Muslims to not buy products from the offending states. Email messages also circulated within and beyond the Middle East. With attachments of the caricatures and the offence they had caused, the messages urged all Muslims to take action. One message, for instance, informed the recipients of the contents of the cartoons, attached their copies, and asked: "You have a father, mother, and sister. What will you do if someone humiliate [sic] them.” Then it called for a boycott of "Danish products such as Nido, Anchor, Laurpack or any Danish product”. Religious leaders also urged worshippers to support the boycott. Within days, dairy products from Denmark and Norway were withdrawn from supermarkets in Saudi Arabia, Kuwait, Qatar, Bahrain and the United Arab Emirates. In some cases, the shelves containing dairy products from these countries were cordoned off with a sign "Danish Products". In others, the products were removed with signage “Danish products were here” (Arla Foods, 2006a).

The boycott seriously affected the exports from Denmark and Norway. Arla Foods, for instance, estimated that the suspension of orders and sales of their food products through some 50,000 outlets in the region would cost DKK 400 million to its shareholders. Concerned at the prospect, it actively engaged the Muslim communities in the region. On 26 January 2006, the Executive Director of the company, Finn Hansen stated:

Arla Foods regrets the effect which the cartoons have had on many Muslims. For many years, Arla has traded, and enjoyed good relations with consumers in the Middle East. In fact, we have more Muslim than Danish consumers. We respect all religions and wish to express our sympathy and understanding for those who 
feel wronged by this incident. Obviously, Arla Foods does not support anything that offends people’s religion or ethnic background (Ibid).

In addition to placing this statement on the company's website, Arla Foods also actively drew attention of Muslims to the regret expressed by Danish government. The Danish ambassador to Saudi Arabia, Hans Klingenberg, for instance, had issued a statement that Denmark respects all religions. While posted on the Danish Embassy website, the media in Saudi Arabia ignored the statement. At the height of the controversy, Arla Foods decided to pay for its publication in Saudi Arabian newspapers as a sponsored advertisement (Arla Foods, 2006b). It also publicised the statements by Danish Muslims thanking the prime minister for his contribution in resolving the conflict and the suggestion for a joint mission of Danish Islamic organisations, the Ministry for Foreign Affairs and the Confederation of Danish Industries to Saudi Arabia and the Saudi Grand Mufti as a means to ending the boycott that had "harmed Danish businesses" (Arla Foods, 2006c). The company, however, was also keen to indicate that it was guided by more than mere business interests. It actively supported the agenda of promoting and supporting interfaith dialogue. Indications to this effect were present during the height of the controversy.

The emergence of alternative diplomatic agents and the continued (even if limited) relevance of traditional diplomats was also reflected in the last days of the cartoon controversy. A constellation of agents worked together appealing for calm and the need to communicate feelings and ideas to avoid future conflicts (BBC News, 2006). Moderate Muslim groups in Denmark and elsewhere in Europe stressed that members of 
the Islamic community would serve the cause of Islam better by peaceful communications instead of resorting to violence. The Catholic Church also expressed regret at the disrespect shown to the Prophet. Governmental leaders (for example, in Pakistan) also urged calm and asked for an end to violent demonstrations as a means of expressing hurt feelings. Governments and civil society groups in western liberal states also actively promoted the cause of interfaith dialogue (Ministry of Foreign Affairs of Denmark, 2006b). Together, these efforts finally took the controversy away from the centre-stage of world politics.

The pro-negotiation agents have not stopped their efforts in the post-controversy days. Danish Muslims are increasingly engaged by the government (Buch-Andersen, 2006). They, in turn, are increasing their efforts to "teach” others about Islam. Even Arla Foods has remained an active diplomatic agent. While relying heavily upon cyberspace and print-media, the company has continued to reaffirm its commitment to interfaith dialogue. Parallel to an advertising campaign to recover the lost economic grounds, it has actively supported humanitarian initiatives in the Middle East. Importantly, it has expressed its intentions "to support activities aimed at creating greater understanding between the world's religions and cultures” (Arla Foods, 2006d). Such a shift in emphasis from purely business interests to acceptance of the significance of interfaith dialogue indicates that the agenda of new diplomats is also expanding. In an era of technological advances and increased globalisation, these agents are emerging as nontraditional agents of diplomacy in areas of religious understanding.

\section{DIPLOMACY AND INTERFAITH: WHITHER NOW?}


The cartoon controversy has established that interfaith dialogue is not the sole domain of either civil society groups or diplomats. Increasing globalisation and the linkages between societal groups across states have created a condition where ideas freely flow and can trans-mutate into something other than their intended meanings. Under such circumstances, misunderstandings can arise and sensibilities can be hurt. Societal groups have acquired an ability to communicate and interpret these messages without necessarily any reference to the established state structures that dealt with the art of negotiations in the past. Given the increased prominence of religion in political discourse, this creates a condition where both governmental and societal groups can create, sustain or resolve conflicts. The chances of their success, even if measured in relative terms, increase if they cooperate in identifying the causes of ideological conflicts and misunderstandings. Civil society groups and diplomatic institutions, in other words, need to cooperate if the agenda of interfaith dialogue is to be successfully implemented.

The notion of interfaith dialogue, however, needs to be broadened beyond involving those from the established religious traditions. The cartoon controversy has amply demonstrated the importance of such a rethinking of the definition of interfaith. Given that a large majority of those living in western liberal democracies either identify themselves as secular or are averse to formally participating in organised religious traditions, a narrow and rigid definition of interfaith runs the risk of excluding large number of those who shape ideas. It also runs the risk of creating an artificial notion of centre and periphery with those from established religious traditions occupying the centre space in interfaith dialogue. The fact that those at the assumed periphery can disrupt the rhythm of any dialogue by questioning the very principles on which it is being conducted 
suggests that including them will serve the purpose of establishing and sustaining real dialogue across civilisational and religious divides.

The broadening of the notion of interfaith needs to be accompanied by expanding the membership of those engaged in the project. Until recently, clergy representing different traditions has predominantly conducted the religious dialogues. Such restrictive participatory arrangements are essentially governed by assumptions that religious clergy play a special role in shaping the views of the masses. While this view may be correct for a minority, the cartoon controversy demonstrated that agents other than the clergy were equally able to contribute to the misunderstandings. While Muslims circulated messages urging other coreligionists to protest the publication of cartoons, those from the western tradition also vented their anger at Islam's perceived intolerance and denial of the right to freedom of speech. That not all of them were from the clergy on both sides suggests that interfaith dialogue needs to draw support from the wider public and give them a sense of ownership of the process as well.

Equally importantly, the question of diversity in religious traditions and gender balance needs to be addressed with reference to interfaith dialogues. The growing emphasis on building bridges across civilisational divides has unfortunately become hostage to two tendencies: first, its emphasis on religious representation has generally excluded those perceived to be "less religious". Even when the scope of representation is broadened, it still remains limited to those who look religious. This problem is particularly significant in terms of representation of Muslims in such dialogues: those subscribing to traditional Islamic dress code receive more attention as worthy participants of interfaith dialogue than the majority of Muslims who opt for less orthodox 
interpretation of their religion. Second, generally the process of engaging people from diverse religious traditions tends to be biased in favour of men. Women tend to remain under-represented despite the fact that they often occupy centre-stage as symbols of religious differences.

Most importantly, the cartoon controversy has highlighted the relevance of perceptions and imagery in creating and sustaining conflicts around religious identities. It has also drawn attention to the need for accepting that all understandings of one's relationship to spatial and spiritual realm can be equally valid. Any attempt to privilege one understanding over another can create conflict or lengthen the time taken to resolve differences. During the cartoon controversy, western societies generally privileged freedom of speech over the Muslim focus on the perceived insensitivity to their notion of sacred spaces. Against the background of western colonisation and a more recent negative focus on Islam, it contributed to ideas of western hostility towards Islam. An expression of understanding of the hurt caused may have avoided a lot of problems that emerged once the issue got out of the control of those who publicised it. Muslims also needed to understand that accurate communication of what is considered sacred and why, might have contributed to some resolution earlier than was the case. Essentially, the controversy has highlighted the need to revisit the logic underlying the dialogues: instead of appropriating “the truth”, all those engaged in interfaith dialogue need to accept that our "Truths" are mere truths for those who view the reality and the world differently. Developing such an approach requires exposure to other religious and cultural traditions. Such a change, in turn, depends upon developing long-term strategies that enable people of all religions to interact and learn from each other. It also depends upon accepting that 
such knowledge is not the route to establishing superiority of one faith/belief system over another.

In the short term, the growing relevance of religion in world politics, magnified through the cartoon controversy, suggests that both diplomatic and governance institutions will increasingly have to deal with future controversy centring round different notions of sacred as well debates on secularism vs religious beliefs. Diplomats need to be trained in religious and cultural diversity, as well as the nuanced differences within religious traditions. This does not supersede the traditional emphasis on issues of "high politics”. Instead, diplomatic training programmes could help those who engage in the art of communication and resolution and management of conflicts, to appreciate the blurring of lines state and non-state spheres. Such understanding would attune them to emerging fault lines linked to religious or cultural beliefs before they result in conflicts. Without such training, we may continue to witness cycles of religion-related conflicts and crises that we cannot afford.

\section{Endnotes}

${ }^{\mathrm{i}}$ Shahadah is the primary declaration of faith by Muslims which states that 'There is no God but Allah, and Prophet Mohammad is God's messenger'.

ii Niqab refers to a particular form of veiling that completely covers a woman's face except for her eyes.

iii Later, Flemming Rose provided a detailed account for his decision to commission these cartoons in terms of a preference for cultural inclusivity of Muslims. See Flemming Rose (2006) "Why I Published the Muhammad Cartoons", SPIEGEL ONLINE, available from 
http://www.spiegel.de/international/spiegel/0,1518,418930,00.html.

iv See, for example, Tariq Ali (2006) “This is the Real Outrage”, Khaleej Times, 15 February.

v See also, Ministry of Foreign Affairs of Denmark (2006) “Danish Prime Minister’s Interview in Al-Arabiya”, Danish Embassy, Madrid, 3 February, available from http://www.ambmadrid.um.dk/da/menu/OmOs/Nyheder/PrimeMinistersInterviewInAlAr abiya.htm.

${ }^{\mathrm{vi}}$ Based on personal communication with a senior Pakistani diplomat on his role during the cartoon controversy, December 2006.

vii The statement built upon the UN General Assembly resolution of 16 December 2005 on the need to combat defamation of religious with specific references to Islam. United Nations, Resolution adopted by the General Assembly, A/Res/60/150, 20 January 2006.

\section{References}

ArabicNews.com (1998) “Crown Prince Hassan: Islamic-Christian Dialogue Important”, 3 March, available from http://www.arabicnews.com/ansub/Daily/Day/980423/1998042301.html. Arla Foods (2006a) “Arla Affected by Cartoons of Muhammad”, available from http://www.arlafoods.com/APPL/HJ/HJ202COM/HJ202D01.NSF/O/3DE8AAFD ECABBA97C12571020061F1C1.

Arla Foods (2006b) “Arla Publishes Danish Government’s Press Release in Saudi Papers”, available from 
http://www.arlafoods.com/APPL/HJ/HJ202COM/HJ202D01.NSF/O/F2B3B702F A17AFE4C12571030056C46D.

Arla Foods (2006c) “Danish Muslim Call off Campaign”, available from http://www.arlafoods.com/APPL/HJ/HJ202COM/HJ202D01.NSF/O/953BC798F EAA6AE8C1257108002C2C7C.

Arla Foods (2006d) “Breakthrough for Arla in the Middle East”, available from http://www.arlafoods.com/appl/hj/hj202com/hj202d01.nsf/O/680DB47E0A10159 EC1257148002E22AC.

BBC News (2004) “Spain Proposes Cultural Alliance”, 22 September, available from http://news.bbc.co.uk/2/hi/europe/3679336.stm.

BBC News (2006) “OIC Denounces Cartoons Violence”, available from http://news.bbc.co.uk/2/hi/south_asia/4736854.stm.

Buch-Andersen, T. (2006) “Denmark Row: The Power of Cartoons”, available from http://news.bbc.co.uk/2/hi/europe/5392786.stm.

Flint, Julie (1995) “Hidden Holy War in the Hills”, The Guardian, 22 July.

Fraerman, Alicia (2004) “Spanish Prime Minister Advocates an Alliance for Peace”, InterPress Third World News Agency, 23 September, available from http://www.chasque.apc.org/ips_eng/notas/2004/09/23/10:40:40.html. Gudmundsson, Hjörtur (2006) “Danish Imams Propose to End Cartoon Dispute”, The Brussels Journal, available from http://www.brusselsjournal.com/node/698. Juste, Carsten (2006) “Honourable Fellow Citizens of the Muslim World”, JyllandsPosten, available from http://www.jp.dk/meninger/ncartikel:aid=3527646. 
Khan, Aamer A. (2006) "Hidden Motives behind Cartoon Riots”, BBC News, available from http://news.bbc.co.uk/go/pr/fr/-/2/hi/south_asia/4716762.stm.

Letter by the Muslim Representatives, 12 October 2005, available from http://www.filtrat.dk/grafik/Letterfromambassadors.pdf.

Ministry of Foreign Affairs of Denmark (2006a) “Ambassador of Denmark Confirms his Country’s Respect to Religion”, Embassy of Denmark, Riyadh, 24 January, available from http://www.drawings.um.dk/en.

Ministry of Foreign Affairs of Denmark (2006b) “Danish Churches Appeal”, Embassy of Denmark, Islamabad, 10 February, available from http://www.ambislamabad.um.dk/en/menu/News/DanishChurchAppeals.htm. Ministry of Foreign Affairs of Denmark (2006c) "Statement by the Danish Prime Minister Anders Fogh Rasmussen Regarding the Drawings of the Prophet Mohammad”, Embassy of Denmark, Riyadh, 31 January, available from http://www.drawings.um.dk/en/menu/news/statementbythedanishprimeministeran dersfoghrasmussenregardingthedrawingsoftheprophetmohammed.htm.

Turkish Press (2006) “Two Killed in Pakistan as EU Tries to Defuse Cartoon Row”, 14 February, available from http://www.turkishpress.com/news.asp?id=108160.

United Nations (2005) “Secretary General Announces Composition of High-Level Group for Alliance of Civilisation”, Secretary-General SG/SM/10073/Rev.1, 2 September, available from, http:www.un.org/News/Press/docs/2005/sgsm10073.doc.htm. Wikipedia (2006) “Jyllands-Posten Muhammad Cartoons Controversy”, available from http://en.wikipedia.org/wiki/Jyllands-Posten_Muhammad_cartoons_controversy. 


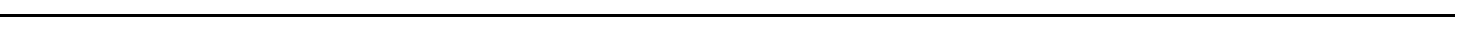

